\title{
Formation of a Knowledge base in the Field of Patenting Technologies and Equipment for Involvement in the Processing and use of Woody Greenery in Industry, Agriculture and in the Social Sphere
}

\author{
Shegelman I. R. ${ }^{1 *}$, Vasilev A. S. ${ }^{2}$, Sukhanov Y. V. ${ }^{2}$, Lukashevich V. M. ${ }^{2}$, Galaktionov O. N. ${ }^{5}$, \\ Kuznetsov A. V. ${ }^{5}$, Krupko A. M. ${ }^{6}$ \\ ${ }^{1}$ Doctor of Technical Sciences, Professor, Cross-cutting technology and economic security, Petrozavodsk State University (PSU), 33, Lenina pr., \\ 185910, Petrozavodsk, Republic of Karelia, Russia \\ ${ }^{2}$ Candidate of Technical Sciences, Associate Professor, Technologies and organizations of the forest complex, Petrozavodsk State University (PSU), 33, \\ Lenina pr., 185910, Petrozavodsk, Republic of Karelia, Russia \\ ${ }^{5}$ Doctor of Technical Sciences, Associate Professor, Technologies and organizations of the forest complex, Petrozavodsk State University (PSU), 33 , \\ Lenina pr., 185910, Petrozavodsk, Republic of Karelia, Russia \\ ${ }^{6}$ Candidate of Technical Sciences, Associate Professor, Mathematical Analysis, Petrozavodsk State University (PSU), 33, Lenina pr., 185910, \\ Petrozavodsk, Republic of Karelia, Russia
}

Received: 14/02/2020 Accepted: 09/07/2020 Published: 20/12/2020

\begin{abstract}
In recent years, the results of intellectual activity - numerous technological and technical solutions - have been patented for the basic operations of the forestry complex. Insufficient attention is paid to the formation of knowledge bases in the field of technologies and equipment for involving non-timber forest resources in the processing. The formation of databases in this area is caused by the identified trends in the development of products from various types of natural raw materials for the pharmaceutical, food, cosmetic industries and other spheres of the social sphere and the economy. Among the types of natural raw materials, an important place is occupied by raw materials with a wide range of biological effects, including woody greens. The development of a knowledge base in the field of involving tree greenery in various spheres of the social sphere and economy was carried out on the basis of a systematic patent search. The analysis made it possible to form a knowledge base about the main most characteristic technological and technical solutions patented in Russia in the field of harvesting, processing and use of greenery of tree species growing in Russia in industry, agriculture and in the social sphere. These solutions are classified according to the types of greenery used (complex of conifers, and in the context of woody greenery of fir, pine, larch, cedar and dwarf cedar, juniper, and deciduous trees). Within each class of patents in the field of wood greenery processing, patents are given taking into account the directions of their use, the effects achieved as a result of the implementation of patented solutions with the allocation of economic entities conducting patenting in the studied area. In this regard, the authors carried out research with the conduct of patent information search, collection and systematization of information. The state and tendencies of directions of patenting in the field of technologies and equipment for the use of tree greenery in industry and in the social sphere are revealed, the main goals of patenting (effects) are determined to achieve which the patented intellectual property objects are considered. The most interesting patents collected during the formation of the knowledge base are presented.
\end{abstract}

Keywords: Knowledge base, Tree greenery, Tree species, Forest complex, Non-timber forest resources, Intellectual property, Plant raw materials, Patent, patent search

\section{Introduction}

The authors believe that in the formation of knowledge bases for various industries of the forestry complex, insufficient attention is paid to the formation of knowledge bases in the field of technologies and equipment for nontimber forest resources. The need to form databases in the field of involving non-timber forest resources in the industrial

Corresponding author: Shegelman I. R., Doctor of Technical Sciences, Professor, Cross-cutting technology and economic security, Petrozavodsk State University (PSU), 33, Lenina pr., 185910, Petrozavodsk, Republic of Karelia, Russia. E-mail: education.com.ru@gmail.com. sphere is caused by the revealed tendencies towards the development of products for various sectors of the economy and social sphere using various types of natural raw materials. Woody greens occupy an important place among these types of natural raw materials. The purpose of the research is to synthesize information to form a knowledge base in the field of creating promising technical solutions for technologies and equipment for involving in the processing and use of greenery in industry, agriculture and in the social sphere. When choosing technologies for such solutions, developers take into account the specifics of the directions for using greens, the breed, and the requirements for the products obtained. Various technologies and equipment have their own certain not only 
advantages, but also disadvantages, the qualitative elimination of which requires abrupt technological and technical solutions. One of the most important factors confirming the level of such decisions is the patenting of the results of their intellectual property by researchers and developers. To achieve this goal with the active use of search engines, library funds, materials of dissertation research, information on the content and results of research contained in articles in special industry journals, as well as materials contained in the knowledge bases of the Russian Science Citation Index and the Federal Institute of Industrial Property. Based on the results of the analysis, the directions of patenting technologies and equipment for involving in the processing and use of tree greenery in industry, agriculture and in the social sphere are identified and classified. The effects (goals) for which the patented technologies and equipment were directed to involve in the processing and use of bark were identified. Organizations conducting research and patenting in the studied area have been identified. The most interesting technological and technical solutions are presented.

\section{Literature Review}

In recent years, scientists [1] have been actively exploring ways to solve the problems of the timber industry complex. At the same time, for the basic operations of the forestry complex, as well as for many other industries, new results of intellectual activity are being developed and patented numerous technological and technical solutions. The development of new objects of intellectual property is carried out on the basis of knowledge bases about the state and development trends of improving (created) objects of intellectual property [2]. At the same time, in the forest industry, the main attention is focused on the formation of knowledge bases in the field of timber harvesting. The authors consider it necessary to note the insufficient attention paid to the formation of knowledge bases in the field of procurement and use of various types of non-wood resources, in particular, woody greenery. As noted in the works [3-6], woody greens are an important source of biologically active products and the potential for widespread use in industry, agriculture and social sphere. According to Shanina [7], the presence of valuable biologically active substances in the tree greenery of Scots pine and the possibility of obtaining medicinal preparations, natural intermediates for perfumery and cosmetic industries, feed additives in animal husbandry and poultry farming from it, creates the preconditions for its complex processing. According to studies [8], the components of extractive substances of wood needles have a wide spectrum of biological activity and can be used to obtain drugs in pharmacology, veterinary medicine, and agriculture. The work [9] shows the promise of using extracts from fir in agriculture, medicine and sports. At the St. Petersburg Forestry University, several technologies were created for the processing of cellulose waste and woody greens with the receipt of such nutritional biocorrectors as phytosterol, betulin, coniferous essential oil, provitamin concentrate, etc., the effectiveness of which as therapeutic and prophylactic agents has been confirmed by research domestic and foreign scientists [10].

The work Zadorozhnaya et al., [11] studied the sensitivity of microorganisms isolated in hatcheries to antibacterial drugs of natural origin obtained from needles. The preparations represented the amount of woody green substances dissolved in water (up to 60\%) (extract of needles of fir, pine, spruce). It has been established that these drugs have antibacterial and fungicidal effects, exhibit anti-inflammatory and woundhealing properties, and have a long-term deodorizing effect.
According to Zhuravleva [12], woody greens, rich in biologically active substances, by using them as a feed additive - a source of proteins, vitamins, microelements, can increase the productivity of farm animals. In the work [13], it is shown that it is promising to increase the feed and nutritional value of feed by using coniferous greens, needles and coniferous flour as sources of vitamins and microelements. In the work Khurshkainen [14], a method was developed for obtaining a biological product "Verva from coniferous tree greenery to stimulate growth and protect plants from infections. The work [15] shows the prospects of using the biostimulants "Verva" and "Verva-spruce" to obtain highquality planting material in forest nurseries. The biostimulator "Verva" is created on the basis of fir tree greenery extract, "Verva-spruce" contains extractive components of spruce tree greenery of European and Siberian spruce. The use of the preparations "Verva" and "Verva-spruce" for pre-sowing seed treatment will shorten the period of growing seedlings and reduce the cost of planting material [16].

In works Filatov [17] it is shown that the use of the biological product "Verva" increases the productivity of fattening pigs, reduces postpartum pathology. At the same time, multiple pregnancies increase, and the newborn young animals have high growth vigor. According to studies [18], the dietary supplements "Verva" helps to increase the average daily gain of pigs by $23,2 \%$, absolute gain - by $23.3 \%$, the age of reaching a live weight of $100 \mathrm{~kg}$ is reduced by 17 days. Under the influence of the additive, the pre-slaughter live weight of pigs increases by $12.9 \%$, the weight of the fresh carcass and the slaughter weight increase by 13.0 and $17.2 \%$, respectively. At the same time, there is an increase in the slaughter yield by $2.6 \%$, the slaughter weight of the carcass and its length increase by 20.2 and $12.9 \%$, respectively. In the inclusion of the fir extract "Verva" in the system of rational nutrition of pigs in during the first 30 days of the feeding period $\mathrm{n}$ It has a positive effect on the fattening and meat qualities of animals. It has been established that the use of the "Verva" supplement for quails improves the biochemical parameters of the hatching egg. In the experimental groups, the content of vitamins B1 and B2 in the egg white is 2.643.46 times and 1.36-1.67 times higher, in the yolk of vitamins B1 and B2 - 2.2-2.6 times and 3.1-27.1\%, carotenoids increased by $14.8-28.2 \%$ compared to the control group, and the acid number was optimal. Improvement of the biological usefulness of hatching eggs contributed to an increase in egg fertilization by $1.25-2.50 \%$, hatching of quail - by $3.75-7.5 \%$, hatchability of eggs - by $3.3-6.49 \%$. The obtained young growth in groups using extractives of fir tree greens had a higher live weight and viability in the first two weeks of life [19]. The use of woody greens makes it possible to obtain a complete feed for cattle [20]. In the work [21], it is shown that the introduction of feed additives from fir needles into the diets of dairy cows stimulates milk productivity without reducing the quality characteristics of milk and shortens the service period. The treatment with the acidic fraction of the carbon dioxide extract of Siberian fir increases the yield of cucumbers by $20 \%$ and shortens their ripening period by $3-4$ days.

One of the most valuable raw material sources of essential oils in the Subarctic region of Russia is the woody greens of the common juniper. Its essential oils have antibacterial activity that inhibits the development of gram-negative bacteria. It has been shown that the use of juniper woody greens is promising for the production of essential oils as components of preparations and products with an antibacterial spectrum of action [22]. The analysis showed that there is a significant amount of serious scientific research in the field of 
technologies and equipment for involving woody greens in the processing. However, despite the formed scientific and technical groundwork, many of these studies are at the development stage and are often not implemented due to the lack of industrial partners and insufficient attention of scientists and developers to patenting the results of their intellectual activity, lack of competitive patented intellectual property. This conclusion is confirmed by the fact that, according to the Federal Institute of Industrial Property, as of May 18, 2020, there are 152 patents for the term "woody green", 73 patents for the term "coniferous greens", and 4 patents for the term "deciduous greens". The number of publications according to the Russian Science Citation Index for the terms "woody green" - 5068, "coniferous green" 7977, "deciduous green" - 1422. Unfortunately, only separate studies [23] are devoted to the procurement of woody greenery. Therefore, despite numerous studies of the procurement, processing and use of woody greenery, additional research is needed to form a knowledge base for the synthesis of new patentable solutions in this area.

\section{Materials and Methods}

The purpose of this work is to synthesize information to form a knowledge base in the field of creating promising technical solutions for technologies and equipment for involving in the processing and use of tree greenery in industry, agriculture and the social sphere. The tasks were set:

- Collection and analysis of data on the most typical Russian patents in the field of harvesting, processing and use of greenery in the context of tree species growing in Russia;

- Classification of patents by types of used tree greenery (complex of conifers, and in the context of tree greenery of fir, pine, larch, cedar and dwarf cedar, juniper, and deciduous trees);

- Determining the directions of patenting technologies and equipment for involving in the processing and use of woody greenery in industry, agriculture and in the social sphere;

- Determining the effects achieved as a result of the implementation of patented solutions for the involvement in the processing and use of woody greenery;

- Identification of business entities conducting research and patenting technologies and equipment for involving in the processing and use of woody greenery.

To achieve the set goal and objectives, the method of system analysis was used, carried out based on the results of the patent information search, information was collected and systematized. The designations are used in this work

- Voronezh State Forestry Academy - VSFA;

- All-Russian Research Institute - ARRI;

- Vologda State Dairy Academy - VSDA

- Far Eastern Research Institute of Forestry - FERIF;

- Institute of Biology of the Karelian Scientific Center of the Russian Academy of Sciences - IBKRC RAS;

- Institute of Physiology of the Komi Scientific Center of the Ural Branch of the Russian Academy of Sciences IPKSCUB RAS;

- Institute of Chemistry of the Komi Scientific Center of the Ural Branch of the RAS - IChKSCUB RAS;

- Kazan National Research Technological University KNRTU;

- Kemerovo Technological Institute of Food Industry Kemerovo TIFP;

- Krasnoyarsk State Agrarian University - KrasnGAU;
- Krasnoyarsk State Trade and Economic Institute KrasnTEI;

- Krasnoyarsk regional fund for support of scientific and scientific and technical activities - KrasnFP;

- Magadan Scientific Research Institute of Agriculture MagniISKh

- Mari State Technical University - MarSTU;

- Scientific Research Institute - SRI

- Research Institute of Veterinary Medicine of Eastern Siberia - RIVMES;

- Scientific and Technical Center for the Development of Advanced Equipment -STCDAE;

- Research and Production Company "Green Chemistry" RPF "Green Chemistry";

- Research and Production Firm "Energy Lesa" - RPF "Energy Lesa";

- Scientific and Technical Center "Khiminvest" - Scientific and Technical Center "Khiminvest";

- Novosibirsk Institute of Organic Chemistry named after N.N. Vorozhtsov of the Siberian Branch of the Russian Academy of Sciences - NovIOCh;

- Scientific Research Institute - Research Institute;

- Limited Liability Company - LLC;

- Northern (Arctic) Federal University - NArFU;

- Siberian State Technological University - SibSTU;

- Riga University Stradins - Riga University. According to the methodology, as research materials at the first stage of the work, the results of extended information and analytical search with the active use of search engines, library collections, dissertation research materials, as well as information about the content and results of research contained in articles in special industry journals were used. At the same time, special attention was paid to the analysis of studies considered in the dissertations of Russian scientists:

- Technology of extractive substances of European spruce greenery (Piceaabies (L) karst) with obtaining biologically active preparations S.N. Vasiliev [3].

- Complex processing of tree greenery and bark of Siberian fir to obtain products with biological activity [24].

- Processing of coniferous greenery using liquefied hydrocarbons [12].

- Influence of extracts from woody greenery and tap sediment as a substrate component on seed germination and growth of Scots pine seedlings.

- Processing of woody greens of Scots pine using waterethanol mixtures: dissertation [7].

- Processing of woody greenery of Scots pine to obtain pectin substances.

- Toxicological and hygienic assessment of biologically active substances from woody greenery and wood.

- Isolation and study of acidic components of lipids in woody greens of fir (Abies sibirica) and spruce (Picea sibirica) [14].

At the second stage of the work, an extended patent information search was organized for inventions and utility models patented in the Russian Federation in the field studied by the authors. At the same time, the materials contained in the knowledge bases of the Russian Science Citation Index and the Federal Institute of Industrial Property were actively used. The analysis identified and classified the directions of patenting technologies and equipment for the involvement in the processing and use of greenery in industry, agriculture and in the social sphere. Particular attention was paid to the effects (goals) to which patented technologies and equipment were directed to involve in the processing and use of woody 
greenery. Organizations conducting research and patenting in the studied area were identified.

\section{Results and Discussion}

As shown above, the theoretical and practical aspects of involving in the processing and use of greenery in industry, agriculture and in the social sphere are considered in the studies of well-known scientists in Russia. In this section, according to the methodology, we focused on patenting developments in this area. Development of new solutions for harvesting woody greenery. NArFU patented a method for separating needles from tree shoots [25]. According to the method, coniferous legs are placed in a chamber with a gas-air environment. In the chamber, coniferous legs are kept in a cryogenic gas-air environment until the protoplasm of connective tissue cells, brachyblast, auxiblast and bound moisture in the cell walls are completely crystallized, followed by the separation of frozen needles from tree shoots by mechanical action Damage to wood and bark does not occur, there are no foreign impurities in the needles, completely valuable components are retained, which improves product quality. The achieved effect is a high-quality product without damaging wood and bark. NArFU patented a cutting device for harvesting and grinding woody greenery. The achieved effect is a decrease in losses and damage to woody greenery, an increase in the productivity of its harvesting. The development of this solution by the named university is given in a patent, according to which the apparatus provides preliminary shaking off of substandard material (dried needles, extraneous litter) [26]. The achieved effect is to improve the quality of harvested woody greenery. VSFA patented a method for processing woody greenery and a device for its implementation [27]. The method includes processing woody greenery in a microwave field and separating it from the branches, and the greenery is precompacted to $300 \ldots 400 \mathrm{~kg} / \mathrm{m} 3$, and the processing is carried out in a microwave electromagnetic field with a frequency of $2450 \mathrm{MHz}$. The achieved effect is to increase the intensity of the drying process of woody greenery and the biological value of the resulting product. The method of sorting felling residues [28] provides for the collection and sorting of felling residues into grains, tops, twigs, branches and green trees when loading the forwarder's body. The achieved effect is the separation of greenery when collecting logging waste. KNRTU has patented a method for the complex processing of woody greenery [29] for obtaining biologically active substances and fodder meal from woody greenery of various species. The achieved effect is an increase in the yield of biologically active substances, obtaining high-quality feed flour due to the protein content in it and reducing energy consumption by more than two times. STC for the development of advanced equipment patented a method for the complex processing of woody greenery [30]. The achieved effect is a reduction in the processing time and an increase in productivity. MarSTU patented an installation for the production of essential oil in the complex processing of wood products [31]. The achieved effect is the creation of a mobile installation for the production of essential oil. Scientific and Technical Center "GreenTex" patented compound feed for cattle, including vitamin flour from woody greenery [32]. The achieved effect is obtaining product with preservation of the original composition of the protein component in the grain.

Development of new solutions for the processing and industrial use of coniferous greenery. KNRTU patented an installation for obtaining a coniferous extract from woody green mass [33]. The achieved effect is a decrease in the temperature of the extraction process and an increase in the content of biologically active substances in the extract. STC "Khiminvest" patented a method for producing extruded coniferous energy additives [34]. The achieved effect is obtaining an additive that allows to stabilize the energy balance of the body and increase the productivity of farm animals. KrasnGAU patented an installation for producing essential oils when organizing small businesses from coniferous tree greenery and bark [35]. The resulting effect is an increase in productivity, yield, quality and elimination of oil loss due to its volatilization, a decrease in fuel consumption. The Institute of Chemistry of the Komi Scientific Center of the Russian Academy of Sciences patented a method for obtaining polysaccharides from the woody greenery of conifers [36]. The achieved effect is the production of pectin polysaccharides and hemicellulose of the glucuronoxylan class with a high yield and a high degree of purification. The Institute of Chemistry of the Komi Science Center of the Russian Academy of Sciences also patented a method for producing a feed additive for animals and birds from coniferous greenery [37]. The achieved effect is an increase in the degree of preservation of carotene, protein and vitamins during the processing of raw materials. KrasnTEI patented a method for extracting essential oil [38]. The achieved effect is the production of essential oil from coniferous greenery, with a pleasant smell and color and bactericidal properties. Riga University (LV) and LLC BFESSE (LV) for the chemical and pharmaceutical industry have patented 2419446 "Composition of dense needles extract for encapsulation, [39]. The achieved effect is to improve the condition of the mucous membranes and increase the protective properties of the body. The All-Russian Research Institute of Potato Economy patented a method for storing planting potatoes [40], according to which, during the treatment period of storage, at the first stage, fumigation and mummification of potato tubers is carried out by means of flameless sublimation of needles. The achieved effect is the elimination of the process of recirculation of pathogens from the potato mound to the storage volume and from the storage facility to the potato mound, increasing the yield of marketable potatoes with good keeping quality. LLC "Fitolonnauka" has patented an absorber of gases and unpleasant odors (variants) and organic fertilizer using waste needles of pine, spruce and other conifers [41]. The achieved effect is to expand the range of absorbers of gases and unpleasant odors, improve the ecological situation and protect the environment. Another patent of Phytolon-nauka LLC protected a remedy for the prevention and treatment of helminthiasis [42], containing an aqueous and/or lipid complex from pine and spruce needles as a plant extract and an active component. The achieved effect is the effectiveness of the prevention and treatment of opisthorchiasis. Scientific and Technical Center "Khiminvest" has patented a method to improve the quality of semen of sire bulls" [43], in which a coniferous energy supplement is added to the daily ration of animals. The achieved effect is an increase in the reproductive abilities of sire bulls.

Development of new solutions for the processing and industrial use of spruce needles. LTD Dve Linii has patented a medical and cosmetic product to protect the skin from sunburn [44]. The achieved effect is increased biological activity and bactericidal effect. Development of new solutions for the processing and industrial use of pine greenery. The Vologda State Agricultural Academy patented a method for the production of a water-soluble dietary supplement from pine greenery and can be used in the production of food [45]. The achieved effect is a decrease in the duration of the production of a water-soluble dietary supplement, an expansion of the range of food products with functional properties. The 
Institute of Biology, Karelian Research Center of the Russian Academy of Sciences, has patented a method for feeding furbearing animals by adding coniferous greenery [46]. The achieved effect is to increase the vitality and safety of weakened mink puppies. RPF "Khiminvest" has patented a coniferous energy additive [47]. The achieved effect is to increase the vitality and safety of weakened mink puppies. RPF "Khiminvest" has patented a coniferous biological active additive to improve the productive qualities of chickens [48]. It contains a bioactive coniferous extract of Scots pine tree greenery. RPF "Khiminvest" also patented a cosmetic body scrub containing crushed pine strobila and coniferous extract of pine greenery [49]. The achieved effect is a synergistic action of bioactive components, exfoliation of the stratum corneum, normalization of metabolism in skin cells, bactericidal, antioxidant and anti-stress effects. RPF "Green Chemistry" has patented a coniferous-glycerin biological active additive to increase the productivity of farm animals and poultry " [50]. The achieved effect is an increase in immuno-biological activity, safety of the livestock, qualitative and quantitative signs of productivity. RPF Energy Lesa for those used in animal husbandry has patented a method for producing a selenium-carotene feed additive using a bioactive coniferous concentrate [51]. The achieved effect is the production of a selenium-carotene feed product. Medovy Dom LLC patented honey with a phyto-additive, including pine needles. The achieved effect is the expansion of the range of honey, which has a new taste, aroma and biological properties. Research Institute of Veterinary Medicine has patented a remedy for the prevention and treatment of mineral deficiency in lambs, including pine needles. LTD Lesnaya Rosa has patented a biologically active agent that includes pine needles for treating udder teats [52]. The achieved effect is the formation of a strong and stable film with antimicrobial and wound-healing effect.

Development of new solutions for processing and industrial use of fir tree greenery. NovIOCh patented a method for obtaining fir oil, chlorophyll-carotene paste, and water fir extract from fir trees [53]. The achieved effect is an increase in the efficiency of separating fir oil, chlorophyllcarotene paste, and aqueous fir extract. KNRTU patented a method for preliminary activation of pressed baker's yeast extract of Siberian fir [54]. The achieved effect is an increase in the lifting force of yeast and an improvement in the physicochemical characteristics of bakery products. AllRussian Research Institute of Tobacco, Shag and Tobacco Products - All-Russian Research Institute of Tobacco, Shag and Tobacco Products received a patent for a method to stimulate the growth and development of tobacco [55], in which the pre-sowing soaking of seeds and processing of seedlings during the formation period is carried out with a growth regulator " Verva ", obtained from green fir trees. The achieved effect is a decrease in the defeat of tobacco by seedling rot, an increase in the yield of seedlings and an increase in yield. KNRTU 2615480 "Method for preliminary activation of pressed baker's yeast", [56]. In this method, Siberian fir extract is used as an additive. The achieved effect is a reduction in the activation time of yeast, an increase in the preservation period of the freshness of the bakery product. Research Institute of Agriculture of the Komi Republic and LLC "Verva" have patented a method to increase the yield of natural hayfields, [57]. According to this method, vegetative plants are treated with a biological product "Verva", extracted from the greenery of fir. The achieved effect is to increase the productivity and quality of grasses of natural hayfields. The Institute of Physiology of the Komi Scientific Center of the Ural Branch of the Russian Academy of Sciences has patented a method for restoring the reserves and the functional state of the body in highly qualified athletes using phytoskipidar baths with the inclusion of crushed fir tree greenery [9]. The achieved effect is to correct the functional state of the body and restore its reserves, increase the performance of athletes in the training and competitive processes. The Institute of Chemistry of the Komi Ural Branch of the Scientific Center of the Russian Academy of Sciences patented a method for processing woody greens of fir, with the isolation of pectin polysaccharides and triterpenic acids from it [37]. The achieved effect is an increase in the yield of target products. NovIOCh patented a yield-increasing agent with fungicidal properties. The product is obtained by extraction of air-dry crushed fir tree greenery with tert-butyl methyl ether. The achieved effect is to reduce the susceptibility to fungal diseases of cereals, legumes and vegetables, stimulate their growth and productivity. The Institute of Chemistry of the Komi Ural Branch of the Scientific Center of the Russian Academy of Sciences has patented a method for stimulating the growth and development of oilseeds, using the biological product Verva, extracted from tree greenery, as a growth regulator. The achieved effect is an increase in the yield of oilseeds and oil content in seeds.

Development of new solutions for the processing and industrial use of cedar and cedar dwarf needles. Magadan Research Institute of Agriculture has patented a method for feeding laying hens [58]. According to the method, a feed additive is used, including flour from the needles of dwarf pine. The achieved effect is an increase in the productive qualities of laying hens and the consumer properties of the products (eggs). Magadan Research Institute of Agriculture has patented a method for feeding lactating cows [59]. According to the method, a feed additive is used, including flour from the needles of dwarf pine. The achieved effect is to increase resistance, cow productivity and profitability of milk production. KrasnGAU patented a drink [60] using coniferous cedar extract. The achieved effect is to obtain a drink with stable taste and aroma qualities during storage. The Novosibirsk Institute of Organic Chemistry has patented a method for producing lambertianic acid from extractives of Siberian cedar greenery", [61]. The achieved effect is to increase the manufacturability of the isolation of lambertianic acid, reduce energy and labor costs, and obtain a product of improved quality.

Development of new solutions for the processing and industrial use of larch needles. Kemerovo TIFP patented a method for producing a plant extract for a composition of medicinal raw materials using Siberian larch needles [62]. The achieved effect is to obtain an extract with a high yield of selenium and biologically active substances of antioxidant action. A special food additive for confectionery products contains a decoction of crushed reindeer lichen, shiksha herb, sphagnum and an infusion of a mixture of willow-herb with larch needles [63]. The achieved effect is to increase the nutritional value of confectionery products, prevent disorders of the nervous system, strengthen immunity. LLC "Agroveit" patented the drug "Raido" for the prevention and treatment of mastitis in cows and the method of its production [64]. When receiving the drug, use larch needles. The achieved effect is the treatment of mastitis in cows. Development of new solutions for the processing and use of juniper needles. SibSTU patented the composition of ingredients for the preparation of aromatic alcohol [65]. The achieved effect is the acquisition of a specific coniferous aroma with spicy notes and a spicy aftertaste. A patented method for preparing a composition for skin regeneration [66], using an extractable composition including stems and needles of juniper. The 
achieved effect is pronounced regenerating properties. Development of new solutions for the processing and industrial use of woody greenery of deciduous plants. The Far Eastern Research Institute of Forestry has patented a method for obtaining a water-oil product from the green wood of deciduous plants [67].

The achieved effect is a high yield of biologically active substances of phenolic nature, an increase in the concentration of polyphenols and flavonoids, expansion of the spectrum of action of the obtained extract Far Eastern Research Institute of Forestry The achieved effect is an increase in the percentage of germination, energy and length of seedlings, a reduction in the time of seed germination and the susceptibility of seeds to fungal mold, an expansion of the range of effective cheap and affordable stimulants Baccata " [68]. The achieved effect is to obtain new products - an extract of biologically active substances and raw wax. LLC "Elmaris" has patented a remedy [69], which uses peach leaves and birch leaves as raw materials. The achieved effect is antioxidant antitumor, immunomodulatory, antidiabetic and antibacterial action. The analysis showed a tendency for the expansion of patenting of inventions and utility models by many universities, scientific organizations and enterprises in the field of involvement in the processing and use of woody greenery in industry, agriculture and in the social sphere. It is obvious that the use of greenery in industry, agriculture and in the social sphere will expand, and accordingly the need for effective technologies and equipment for its involvement in processing and use will expand.

The analysis made it possible to form a knowledge base on the main most characteristic technological and technical solutions patented in Russia in the field of harvesting, processing and use of greenery of tree species growing in Russia in industry, agriculture and in the social sphere. These solutions are classified according to the types of greenery used (complex of conifers, and in the context of woody greenery of fir, pine, larch, cedar and dwarf cedar, juniper, and deciduous trees). Within each class of patents in the field of wood greenery processing, patents are given taking into account the directions of their use, the effects achieved as a result of the implementation of patented solutions with the allocation of economic entities conducting patenting in the studied area. The knowledge base formed during research can be successfully used as a choice of analogues and prototypes for the synthesis of new patentable solutions.

\section{Conclusions}

1. In recent years, the results of intellectual activity have been patented for the basic operations of the forestry complex numerous technological and technical solutions. The development of new objects of intellectual property is necessary in this area on the basis of knowledge bases about the state and development trends of improving (created) objects of intellectual property. The authors who form knowledge bases in various fields believe that when forming knowledge bases for various industries of the forestry complex, insufficient attention is paid to the formation of knowledge bases in the field of technologies and equipment for non-timber forest resources. The need to form databases in the field of involving non-timber forest resources in the industrial sphere is caused by the revealed tendencies towards the development of products for various sectors of the economy and social sphere using various types of natural raw materials. Woody greens occupy an important place among these types of natural raw materials.
2. The analysis showed the presence of a significant amount of serious scientific research in the field of technologies and equipment for involving woody greens in the processing. However, despite the formed scientific and technical groundwork, many of these studies are at the development stage and are often not implemented due to the lack of industrial partners and insufficient attention of scientists and developers to patenting the results of their intellectual activity, lack of competitive patented intellectual property.

3 . The purpose of the research is to synthesize information to form a knowledge base in the field of creating promising technical solutions for technologies and equipment for involving in the processing and use of tree greenery in industry, agriculture and the social sphere. When choosing technologies for such solutions, developers take into account the specifics of the directions for using woody greenery, species, requirements for the products obtained. Various technologies and equipment have their own certain not only advantages, but also disadvantages, the qualitative elimination of which requires abrupt technological and technical solutions. One of the most important factors confirming the level of such decisions is the patenting of the results of their intellectual property by researchers and developers.

4. There is a tendency towards the expansion of patenting of inventions and utility models by many universities, scientific organizations and enterprises in the field of involvement in the processing and use of woody greenery in industry, agriculture and in the social sphere. It is obvious that the use of greenery in industry, agriculture and in the social sphere will expand, and accordingly the need for effective technologies and equipment for its involvement in processing and use will expand.

5. The analysis made it possible to form a knowledge base about the main most characteristic technological and technical solutions patented in Russia in the field of harvesting, processing and use of greenery of tree species growing in Russia in industry, agriculture and in the social sphere. These solutions are classified according to the types of greenery used (complex of conifers, and in the context of woody greenery of fir, pine, larch, cedar and dwarf cedar, juniper, and deciduous trees). Within each class of patents in the field of wood greenery processing, patents are given taking into account the directions of their use, the effects achieved as a result of the implementation of patented solutions with the allocation of economic entities conducting patenting in the studied area.

6. The knowledge base formed during research can be successfully used as a choice of analogs and prototypes for the synthesis of new patentable solutions.

\section{Ethical issue}

Authors are aware of, and comply with, best practice in publication ethics specifically with regard to authorship (avoidance of guest authorship), dual submission, manipulation of figures, competing interests and compliance with policies on research ethics. Authors adhere to publication requirements that submitted work is original and has not been published elsewhere in any language.

\section{Competing interests}

The authors declare that there is no conflict of interest that would prejudice the impartiality of this scientific work. 


\section{Authors' contribution}

All authors of this study have a complete contribution for data collection, data analyses and manuscript writing

\section{References}

1. Shegelman IR, Vasilev AS. The analysis of the research areas in Russian timber industry using the knowledge base on the scientific publications of Russian researchers. Journal of Advanced Research in Dynamical and Control Systems. 2020;12(02):62.

2. Vasilev AS, Shegelman IR, Galaktionov ON, Kuznetsov AV, Sukhanov YV, Shtykov AS. Using the Knowledge Base as a Tool for Improving Forestry Technology (By Example, Harvester Head). Journal of Computational and Theoretical Nanoscience. 2019 Jul 1;16(7):3076-86.

3. Vasiliev SN. Technology of extractive substances of European spruce greenery (Piceaabies (L) karst) with obtaining biologically active preparations. St. Petersburg. 2000.

4. Godovalov GA, Zalesov SV, Korostelev AS. Organization of forest use: non-timber products. Moscow. 2018.

5. Zhuravleva LN, Devyatlovskaya AN, Rubchevskaya LP. Woody greens of Scots pine - a promising source of biologically active substances. Bulletin of the Krasnoyarsk State Agrarian University. 2008;3:166-169.

6. Kozlova LP, Kukina TP, Malykhin EV. Fractionation and chemical composition of highly volatile compounds of the essential extract of fir tree greenery. Chemistry of vegetable raw materials. 2005; $1: 19-24$

7. Shanina EV. Processing of woody greenery of Scotch pine using water-ethanol mixtures. Krasnoyarsk. 2016.

8. Nikonova NN, Khurshkainen TV, Koroleva AA, Kuchin AV. Diterpenic acids of woody greens Pinus silvestris L. Butlerov Communications. 2016;9:25-28.

9. Garnov IO, Boyko ER, Kuchin AV. Patent of the RF No. 2630980. A method for restoring reserves and functional state of the body using phytokipidar baths. Izvestia of the Komi Scientific Center of the Ural Branch of the Russian Academy of Sciences. 2017;3(19):44-52.

10. Nekrasova VB, Bezborodova TG. Obtaining and application of biocorrectors of nutrition from tree biomass. Bulletin of the St. Petersburg Forestry Academy. 2012;198:190-201

11. Zadorozhnaya MV, Lysko SB, Portyanko AV. Laboratory tests of new herbal preparations for the disinfection of poultry farming objects. Glavny Zootechnik. 2019;9:9-16.

12. Zhuravleva LN. Processing of coniferous greenery with the use of liquefied hydrocarbons. Krasnoyarsk. 2005.

13. Ulitko VE, Pykhtina LA, Desyatov OA. Increasing the productive action of feed in the production of milk and meat in the Middle Volga region. Ulyanovsk. 2016.

14. Khurshkainen TV. Isolation and study of acidic components of lipids in woody greens of fir (Abies sibirica) and spruce (Picea sibirica). Syktyvkar. 2004

15. Andreeva EM, Stetsenko SK, Kuchin AV. The influence of growth stimulants of natural origin on coniferous seedlings. Forestry journal. 2016;3(23):10-19.

16. Khurshkainen TV, Andreeva EM, Stetsenko SK. Influence of biological products Verva and Verva-spruce on the growth of Scots pine seedlings. Chemistry of vegetable raw materials. 2019;1:295-300.

17. Filatov AV, Kubasov OS, Khurshkainen TV, Kuchin AV. Prevention of postpartum pathologies in sows and increasing the viability of piglets. Questions of legal regulation in veterinary medicine. 2014;3:171-174.

18. Shemuranova NA, Filatov AV, Sapozhnikov AF. Fattening and meat qualities of pigs when using the Verva fir extract. An Agrarian Science of Euro-North-East. 2016

19. Filatov AV, Pitirimov AS, Sapozhnikov AF. Increasing the reproductive function of quails by using Verva bioadditives. Issues of legal regulation in veterinary medicine. 2017;3:145148.

20. Prosvirnikov DB, Akhmetshin IR, Saldaev VA. Patent of the RF No. 2673753. Complete feed for cattle and method for its production. Scientific and technical center "GreenTex". 2018
21. Zharikov, Ya.A. \& Khurshkainen, T.V. Influence of fir feed additives on the productivity of dairy cows. Zootechnia. 2011;5:9-11.

22. Samsonova NA, Gusakova MA, Bogolitsyn KG. Component composition and antibacterial activity of Juniperus communis 1 subarctic zone of Russia. Siberian forest journal. 2020;2:31-39.

23. Posmetyev VI, Latysheva MA. On the substantiation of the method for separating woody greenery by microwave heating and the main parameters of the installation for its implementation. Forestry journal. 2018;2(30):6-16.

24. Ushanova VM. Complex processing of tree greenery and bark of Siberian fir to obtain products with biological activity. Krasnoyarsk. 2012

25. Melekhov VI, Babich NA, Antonov AM. Patent of the RF No. 2705294. Method for separating needles. Northern (Arctic) Federal University. 2019.

26. Maksimov EI, Fedorchenko IS, Maksimov AE. Patent of the RF No. 152460. Apparatus for harvesting and crushing woody greenery. SibSTU. 2015.

27. Posmetyev VI, Kalashnikova OS, Sviridov LT, Posmetyeva TM Patent of the RF No. 2308827. Method for processing woody greenery and device for its implementation. 2007.

28. Mokhirev AP, Zyryanov MA, Bezrukikh YuA. Patent of the RF No. 2624738. Method for sorting felling residues. KrasnFP. 2017.

29. Ziatdinova DF, Safina AV, Timerbaev NF. Patent of the RF No. 2655343. "Method for complex processing of woody greenery. KNITU. 2018.

30. Safin RR, Voronin AE, Safin RG. Patent of the RF No 2404238. Method for complex processing of woody greenery. Scientific and Technical Center for the Development of Advanced Equipment. 2010.

31. Demitrova IP, Telitsyn GE, Chemodanov AN. Patent of the RF No. 123776 Installation for the production of essential oil. MSTU. 2013.

32. Prosvirnikov DB, Zakirov SR, Gilfanov KKh, Taimarov MA Complete feed based on wood and plant waste and technology for its preparation. Woodworking industry. 2018;2.

33. Timerbaev NF, Safina AV, Ziatdinova DF. Patent of the RF No. 2624922. Installation for obtaining coniferous extract from woody green mass. KNITU. 2017.

34. Korotkiy VP, Zenkin AS, Ryzhov VA. Patent of the RF No. 2536946. A method for producing an extruded coniferous energy additive. Scientific and Technical Center "Khiminvest". 2014

35. Nevzorov VN, Samoilov VA, Matskevich IV, Yarum AI. Patent of the RF No. 2634045. Plant for processing vegetable raw materials. " KrasnGAU. 2017.

36. Patova OA, Makarova EN, Shakhmatov EG. Patent of the RF No. 2448119. Method for producing polysaccharides from woody greenery of coniferous plants. Institute of Chemistry, Komi Scientific Center, Ural Branch of the Russian Academy of Sciences. 2012

37. Kuchin AV, Khurshkainen TV, Skripova NN, Chukichev VM. Patent of the RF No. 2402233. Method for producing a coniferous feed additive. Institute of Chemistry, Komi Science Center. 2010

38. Pankiv OG, Demina LN, Parshikova VN. Efficiency of processing of tree greens of fir by different methods Fundamental research. 2012;1:168-171.

39. Rubens Y, Daberte I, Barene I, Daugavietis M. Patent of the RF No. 2419446. Composition of dense needles extract for encapsulation, Riga University (LV) and LLC "BF-ESSE" (LV) 2011

40. Kalikin AS, Kuchumov NN, Savenkova EN. Patent of the RF No. 2437273. Method for storing planting potatoes and arrangement of a bunker potato storage. All-Russian Research Institute of Potato Farming. 2011.

41. Nekrasova VB. Patent of the RF No. 2493905. Absorber of gases and unpleasant odors (options) and organic fertilizer. LLC "Fitolon-Science". 2013.

42. Krasnov EA, Kaminsky IP, Nekrasova VB. Patent of the RF No. 2493905. Means for the prevention and treatment of 
helminthiasis, in particular opisthorchiasis. LLC "FitolonScience". 2013.

43. Zenkin AS, Korotkiy VP, Kirdyaev VM. Patent of the RF No. 2579179. A method for improving the quality of semen of sire bulls, Scientific and Technical Center "Khiminvest". 2016.

44. Teplov VA. Patent of the RF No. 2475230. Medical and cosmetic product for protecting the skin from sunburn. LLC "Two lines". 2013.

45. Okhrimenko OV, Golovlev DA, Ryzhkova IP. Patent of the RF No. 2525264 Method for the production of a water-soluble dietary supplement from woody greens of pine, and can be used in the production of food. Vologda State Art Museum. 2014.

46. Chernobrovkina NP, Robonen EV, Makarova TN. Patent of the RF No. 2540354. Method of feeding fur-bearing animals. Institute of Biology, KarRC RAS. 2015.

47. Korotkiy VP, Ryzhov VA, Turubanov AI. Patent of the RF No. 2543814. Coniferous energy additive. Scientific and Technical Center "Khiminvest". 2015.

48. Korotkiy VP, Prytkov YuN, Marisov SS. Patent of the RF No. 2515015. Coniferous dietary supplement enriched with 1arginine to improve the productive qualities of chickens. Scientific and Technical Center "Khiminvest". 2014.

49. Korotkiy VP, Mukhina IV, Marisov SS, Fedosova ME. Patent of the RF No. 2602475. Cosmetic body scrub. Scientific and Technical Center "Khiminvest". 2016.

50. Korotkiy VP, Prytkov YuN, Marisov SS. Patent of the RF No. 2579494. Coniferous-glycerin biological active additive for increasing the productivity of farm animals and poultry. RPF "Green Chemistry". 2016.

51. Marisov SS, Ryzhov VA, Korotkiy VP. ePatent of the RF No. 2622262. A method for producing a selenium-carotene feed additive using a bioactive coniferous concentrate. RPF Energy Lesa. 2017.

52. Fedosova ME, Ryzhova ES, Kukinova LI. Patent of the RF No. 657428. Biologically active agent for the treatment of udder teats. LLC Forest Dew. 2018.

53. Popov SA, Shevtsov SA, Kozlova LP. Patent of the RF No. 2530656. Method for processing fir tree greens to obtain fir oil, chlorophyll-carotene paste, and water fir extract. " NovIOCh. 2014.

54. Levashov RR, Mingaleeva ZSh, Reshetnik OA. Patent of the RF No. 2656397. Method for pre-activation of pressed baker's yeast. " KNITU. 2018.

55. Khurshkainen TV, Kuchin AV, Plotnikova TV, Salomatin VA. Patent of the RF No. 2575105. Method for stimulating the growth and development of tobacco. Institute of Chemistry, Komi Ural Branch, Scientific Center of RAS. 2016.

56. Levashov RR, Danilova AV, Mingaleeva ZSh, Reshetnik OA. Patent of the RF No. 2615480. Method for preliminary activation of pressed bakery yeast. " KNITU. 2017.

57. Khurshkainen TV, Kuchin AV, Skripova NN. Patent of the RF No. 2582989 "Method for increasing the yield of natural hayfields." Research Institute of Agriculture of the Komi Republic and LLC Verva. 2016.

58. Ignatovich LS. Patent of the RF No. 2629993. A method of feeding laying hens, which contributes to increasing the productive qualities of laying hens and consumer properties of the products (eggs). Magadan Research Institute of Agriculture. 2017.

59. Kuzmina, I.Yu. (16.07.2019). Patent of the RF No. 2694615. Method for feeding lactating cows. Magadan Research Institute of Agriculture.

60. Rygalova EA, Velichko NA, Terent'ev VI. Patent of the RF No. 2624965. Non-alcoholic carbonated drink "Ruby sun". KrasnGAU. 2016.

61. Popov SA, Kozlova LP, Shpatov AV. Patent of the RF No. 2436781. A method of producing lambertianic acid from extractives of Siberian cedar green wood. Novosibirsk Institute of Organic Chemistry. 2011.
62. Mayurnikova LA, Gorelikova GA, Shigina EV, Shchipitsyn SK. Patent of the RF No. 2391875. A method for producing a plant extract with a high selenium content. Kemerovo TIFP. 2010.

63. Melnikova VV. Patent of the RF No. 2630494. Food additive for confectionery and a method for its production (options). 2017.

64. Solodovnikova ES, Kolesnik AB, Aminova AL, Rameev TV. Patent of the RF No. 2699723. Preparation "Raido" for the prevention and treatment of mastitis in cows and a method for its production. LLC "Agroveit". 2019.

65. Velichko NA, Ayoshina EN, Matveenko EV. Patent of the RF No. 2542966. Composition of ingredients for the preparation of aromatic alcohol used in special vodka. SibSTU. 2015.

66. Sbezhneva SA. Patent of the RF No. 2639094. Method for preparing a composition for skin regeneration. 2017.

67. Kolesnikova RD, Tagiltsev YuG, Tsyupko VA. Patent of the RF No. 2518281. A method for producing a water-oil product from woody greens of deciduous plants. Far Eastern Research Institute of Forestry. 2014.

68. Rubchevskaya LP, Petukhova MS. Method for processing woody greenery Malus Baccata. SibSTU. 2012.

69. Safonova GM, Abasheev ESh. An antioxidant, antitumor, immunomodulatory, antidiabetic and antibacterial agent. Elmaris LLC. 2016. 